\title{
CALON PERSEORANGAN DALAM PEMILIHAN UMUM KEPALA DAERAH
}

\author{
Sri Warjiyati \\ Universitas Islam Negeri Sunan Ampel Surabaya | warjiyatisri@gmail.com.
}

\begin{abstract}
This article discusses the individual candidate in the general election of regional head in political jurisprudence perspective. Before the Mahkamah Konstitusis decision No. 5/PUU-V/2007 pointed out, the individual candidate could have enter the two political institutions; first, in the 2004 general election, the individual candidate competed to get into the institution of the Regional Representative Council of the Republic of Indonesia; second, Undang-Undang No. / / tahun 2006 regarding with the Government of Aceh where the individual candidate could compete with the candidates promoted by the national political party in electing the regional head in all over Aceh. The decision of Mahkamah Konstitusi No. 5/PUU-V/ means that the local head election held in various regions can include the individual independent candidate. In political jurisprudence perspective, mechanism of the individual candidacy in the election has already in accordance with the concept of maslahah al-ammah ie. hifdz alummah. In this case, any of the individual independent candidates who nominate themselves as the regional head cannot be discriminated and they deserve the right to nominate to be in line with the Mahkamah Konstitusis decision.
\end{abstract}

Keywords: Candidate, individual, local election, jurisprudence, siyasah

Abstrak: Artikel ini membahas tentang calon perseorangan dalam pemilihan umum kepala daerah dalam perspektif fikih siyasah. Sebelum Keputusan Mahkamah Konstitusi No. 5/PUU-V/2007 keluar, calon perseorangan bisa memasuki dua lembaga politik; Pertama, dalam pemilu 2004 calon perseorangan berlomba-lomba masuk ke lembaga Dewan Perwakilan Daerah Republik Indonesia (DPD RI); Kedua, dengan Undang-Undang No. I I Tahun 2006 tentang Pemerintahan Aceh, calon perseorangan bisa bersaing bersama calon yang diusung oleh partai politik atau gabungan partai politik nasional dalam pemilihan 
kepala daerah se-Aceh. Keluarnya Putusan Mahkamah Konstitusi No. 5/PUU-V/2007, berarti pemilihan kepala daerah yang digelar di berbagai daerah dapat mengikutsertakan pasangan calon perseorangan. Dalam perspektif fikih siyasah, mekanisme pencalonan perseorangan dalam pemilukada sesuai dengan konsep maslahah ammah yaitu hifdz al-ummah. Dalam hal ini siapapun calon perseorangan yang maju sebagai kepala daerah tidak bisa didiskriminasi dan berhak mendapatkan hak untuk mencalonkan diri sehingga sejalan dengan keputusan MK tersebut.

Kata Kunci: Calon, perseorangan, pemilukada, fikih, siyasah.

\section{Pendahuluan}

Pemilihan kepala daerah merupakan salah satu instrumen untuk memenuhi desentralisasi politik dimana dimungkinkan terjadinya transfer lokus kekuasaan dari pusat ke daerah. Pemilihan kepala daerah sebagaimana pemilu nasional merupakan sarana untuk memilih dan mengganti pemerintahan secara damai dan teratur. Melalui pemilihan kepala daerah, rakyat secara langsung akan memilih pemimpinnya di daerah sekaligus memberikan legitimasi kepada siapa yang berhak dan mampu untuk memerintah. Melalui pemilihan kepala daerah perwujudan kedaulatan rakyat dapat ditegakkan. Pemilihan kepala daerah dengan kata lain merupakan seperangkat aturan atau metode bagi warga negara untuk menentukan masa depan pemerintahan yang absah.

Kepala daerah dan wakil kepala daerah adalah kepala pemerintahan daerah yang dipilih secara demokratis. Pemilihan secara demokratis yang dimaksud adalah pemilihan yang dilakukan oleh rakyat secara langsung yang persyaratan dan tata caranya di dalam peraturan perundang-undangan. Hal ini sejalan dengan pasal 56 Undang-undang Nomor 32 Tahun 2004 yang 
menyatakan bahwa kepala daerah dan wakil kepala daerah dipilih dalam satu pasangan calon yang dilaksanakan secara demokratis berdasarkan asas langsung, umum, bebas, rahasia, jujur, dan adil.

Pengaturan hukum mengenai pemilihan umum kepala daerah memperlihatkan perkembangan dan dinamika yang positif bagi perwujudan kehidupan demokrasi di Indonesia, dengan membuka ruang politis dan hukum bagi kesempatan calon perseorangan, selain calon yang diusung partai politik, untuk mengikuti pemilihan kepala daerah baik ditingkat provinsi, kabupaten, maupun kota. Dinamika hukum dan kehidupan politik dalam kaitan pelaksanaan pemilu kepala daerah secara langsung, memperlihatkan perkembangan positif dimana amanat konstitusi Negara, UUD Tahun 1945 telah mengatur hak politik warga Negara yang sama di hadapan hukum dan pemerintahan telah terakomodasi, direspon dan dilaksanakan secara konsisten tanpa perlakuan diskriminasi.

Berdasarkan latar belakang di atas, dalam makalah ini dibahas tentang calon perseorangan dalam pemilukada ditinjau dari perspektif fikih siyasah.

\section{Pemilihan Kepala Daerah secara Langsung}

Berdasarkan pada pengalaman sejarah republik ini sampai tujuh tahun paca Orde Baru, pemilihan kepala daerah di tingkat provinsi dan kabupaten/kota selalu dilaksanakan dengan sistem perwakilan. Artinya, kepala daerah baik gubernur maupun bupati/walikota hanya dipilih oleh para anggota DPRD. Pengalaman selama itu pula, pemilihan kepala daerah melalui sistem perwakilan, tidak pernah dapat memuaskan hati nurani dan keinginan rakyat secara ideal dan semestinya, selain prosesnya yang tidak transparan dan akuntabel, pelaksanaannya 
seringkali dikooptasi oleh kekuasaan partai politik di tingkat pusat. ${ }^{1}$ Sementara itu, proses penyelenggaraannya sulit terlepas dari praktik money politics untuk tujuan memenangkan pemilihan di DPRD provinsi dan DPRD kabupaten/kota.

Lahirnya UU Pemerintahan Daerah No. 22 Tahun 1999 yang kemudian diubah dengan undang-undang No. 32 Tahun 2004 telah memberikan harapan baru bagi bangsa ini untuk perubahan sistem politik yang otoriter menuju sistem politik yang demokratis. Berdasarkan UU Pemerintahan Daerah yang baru ini, terlepas dari segala kekurangannya, diharapkan terjadi perubahan besar yang mendasar menuju otonomi daerah yang sesungguhnya.

Selama periode pertama bulan Juni hingga Desember 2005, telah dilaksanakan 212 pemilihan kepala daerah langsung di daerah baik di tingkat provinsi maupun kabupaten/kota, sedangkan sampai dengan Maret 2006, pemilihan kepala daerah telah dilaksanakan di 230 daerah. $^{2}$ Dalam sistem politik Indonesia masa transisi, tentunya pelaksanaan pemilihan kepala daerah langsung bukan hanya sekedar amanat konstitusi yang mengikuti sistem pemilihan dalam membangun sistem politik yang demokratis.

Undang-Undang No. 32 Tahun 2004 memang tidak secara implisit memberikan definisi yang tegas mengenai sistem

\footnotetext{
' UU No. 5 Tahun 1974 mengatur pemilihan kepala daerah yang tidak memberikan peluang bagi kebebasan kandidat dan mekanisme penyelenggaraan pemilihan. Adanya fenomena sebelum UU. No. 22/1999 ada, hampir sebagian besar gubernur termasuk juga bupati/walikota yang dipilih anggota legislative harus mendapat "restu" dari Jakarta, di sebagian provinsi di Indonesia, gubernur yang dipilih tidak pernah berasal dari daerah yang bersangkutan, tapi didrop dari pusat atas "restu dan otoritas cendana". Fenomena seperti ini terjadi diwilayah yang dinilai kurang maju, terutama dari sisi SDMnya. Misalnya, gubernur Bengkulu, Jambi dan Riau pada masa Orde Baru, jarang sekali yang berasal dari putra daerah sendiri. Untuk wilayah Sumatra, gubernur $\mathrm{KDH}$ yang berasal dari putra daerah hanya dari provinsi Sumatra Utara, Aceh, Sumatra Selatan, begitu pula di Kalimantan dan Irian Jaya.

2 Sumber Depatemen Dalam Negeri, Laporan Pelaksanaan Pemilihan, Pengesahan dan Pelantikan KDH dan WKDH, (Jakarta: 29 Maret 2006)
}

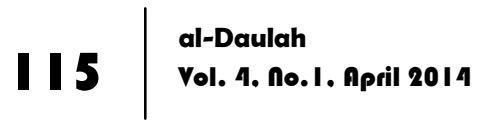


pemilihan kepala daerah yang digunakan. Namun paling tidak hal itu dapat dilihat dari aturan yang dianut dalam pasal 56 sampai pemilihan kepala daerah dan wakil kepala daerah; Pasal 107 dan 108 tentang penetapan calon terpilih dan pelantikannya; serta peraturan pelaksanaannya yang diatur dalam PP No. 6 Tahun 2005.

Sistem yang dianut dalam pemilihan kepala daerah dan wakil kepala daerah menggunakan sistem pemilihan langsung oleh pemilik (direct vote) berdasarkan suara mayoritas absolut dan mayoritas sederhana. Hal ini disebut juga plural majority dengan two round system. ${ }^{3}$ Para pemilih melakukan pencoblosan tanda gambar pasangan kandidat yang diinginkan sesuai keinginan nurani mereka. Pasangan calon yang memperoleh suara 25\% lebih atau disebut juga mayoritas sederhana (simple majority) dapat ditetapkan sebagai pemenang, jika tidak terdapat pasangan calon yang memperoleh suara 50\% lebih, atau disebut dengan istilah mayoritas mutlak (absolute majority). ${ }^{4}$

${ }^{3}$ Lihat I Ketut Putra Erawan, "Logika Perubahan dan Keterlanjutkan Sistem Pemilihan Umum bagi Indonesia 2009," makalah disampaikan pada seminar Mencari Format Baru Pemilu dalam Rangka Penyempurnaan UU Bidang Politik, kerjasama Departemen Dalam Negeri dan Lembaga IImu Pengetahuan Indonesia, Jakarta, 10 Mei 2006.

4 Dalam mekanisme pengambilan keputusan di lembaga-lembaga UE sebagai perbandingan dengan istilah yang digunakan dalam khasanah perpolitikan di Indonesia, terdapat tiga tingkat standart dasar dalam pengambilan keputusan. Pertama, simple majority, yaitu pengambilan keputusan berdasarkan suara 25\% lebih, dalam hal ini diterjemahkan sebagai mayoritas sederhana. Kedua, qualified majority, yaitu pengambilan keputusan berdasarkan suara mayoritas $50 \%$ lebih suara, dalam hal ini kita terjemahkan sebagai mayoritas bersyarat. Dan Ketiga, abso/ute majority, yaitu pengambilan keputusan berdasarkan suara terbanyak mutlak $75 \%$ lebih suara, dalam hal ini dapat diterjemahkan menjadi mayoritas mutlak. Berbeda dengan model UE di atas, Selandia Baru memberikan batasan absolute majority hanya dalm hitungan "more han half (i.e. 50\%=I);" sementara ukuran simpel majority disebut sebagai : :more votes or seats than any other person or party, but less than an absolute majority."Dengan demikian, Indonesia menggunakan standart yang sama dengan Selandia Baru tersebut. Lebih lanjut lihat, Electoral Commission, Everything You Need to Know about Voting Under MMP, (Wellington: GP Publication, 1996), 64 dan 84; juga Electoral Commission, The New Zealand Electoral Compendium, (Wellington: 1997), 157 dan 17. 
Dalam penentuan pemenangnya, jika kita berpatokan kepada aturan yang dirumuskan dalam Pasal 107 Undang-Undang No. 32 Tahun 2004 ini, maka pemilihan kepala daerah langsung ini pada dasarnya menggunakan system alternative vote; yaitu jika tidak dicapai perolehan suara $50 \%$ lebih oleh salah satu pasangan clon kepala daerah dan wakil kepala daerah (gurbernur maupun bupati/walikota) dalam pemilihan, maka pasangan calon yang mendapatkan suar lebih 25\% suara sah dapat ditetapkan sebagai pemenang dalam pemilihan kepala daerah ini. Alternatif kedua ini menggunakan standar perolehan suara hanya lebih dari 25\% dari total suara sah yang diraih oleh pasangan calon. Penentuan angka perolehan 25\% lebih suara sah ini dimaksudkan untuk menghindari terjadinya dua kali pemilihan, yang mengandung resiko mahalnya biaya pemilihan yang harus diemban oleh pemerintah dan pemerintah daerah.

\section{Calon Perseorangan dalam Pemilihan Umum Kepada Daerah}

Lahirnya UU. No. 22 Tahun 2007 tentang penyelenggara pemilu telah merevisi ketentuan penyelenggaraan yang diatur dalam UU No. 32 Tahun 2004. UU No. 22 Tahun 2007 meletakkan pemilihan kepala daerah sebagai bagian dari rezim pemilu sehingga KPU dengan independensinya bertanggungjawab menyelenggarakan pemilihan kepala daerah. Demikian juga dalam pembentukan Badan Pengawas Pemilu (atau panitia Pengawas di tingkat lokal). UU No. 22 Tahun 2007 mengatur pembentukan dan rincian tugasnya serta dijamin independensinya. Perubahan Kedua UU No. 32 Tahun 2004 yang dituangkan dalam UU No. 14 Tahun 2008 juga telah melakukan revisi substansial terhadap penyelenggaraan pemilihan kepala daerah khususnya dalam mengakomodasi hadirnya calon perseorangan. Adanya 
pertimbangan ini perlu diciptakan undang-undang tersendiri (khusus) untuk mengatur penyelenggaraan pemilihan kepala daerah sehingga terwujud pemilihan kepala daerah yang lebih berkualitas dan demokratis. Oleh karena itu, dari prespektif penghormatan terhadap hak asasi manusia hal ini bermakna bahwa setiap orang berhak turut serta dan memperoleh kesempatan yang sama dalam pemerintahan, khususnya pengisian jabatan sebagai kepala daerah dan wakil kapala daerah di tingkat propinsi, kabupaten, atau kota, melalui pencalonan dalam Pemilu kepala daerah.

Dalam kaitan dengan problematika konstitusional dan yuridis-politis sebagaimana diuraikan di atas, kemudian pada tahun 2007 atas dasar pengajuan uji materiil UUPD 2004 atas UUD 1945, atau disebut juga sebagai pengujian konstitusionalitas UU atas UUD Tahun 1945 (constitutional review) ${ }^{5}$ yang pernah diajukan oleh Lalu Ranggalawe, Mahkamah Konstitusi (MK) melalui Putusan No. 5/PUU-V/2007 tanggal 23 Juli 2007 menyatakan bahwa Pasal 56 ayat (2) UUPD 2004 yang hanya memperbolehkan pasangan calon partai politik atau gabungan partai politik dalam pemilihan kepala daerah sebagai inkonstitusional, atau bertentangan dengan konstitusi UUD 1945. Dengan demikian, salah satu substansi penting dari Putusan MK tersebut adalah membuka ruang konstitusional untuk memberi kesempatan bagi bakal calon perseorangan, selain yang berasal dari partai politik atau gabungan partai politik, sepanjang memenuhi persyaratan sebagaimana dimaksud pasal 58 UUPD 2004 melalui mekanisme yang demokratis dan transparan.

\footnotetext{
${ }^{5}$ Retno Saraswati,"Calon Perseorangan dalam Pemilihan Kepala daerah, suatu Tinjauan Filosofis", dalam Jurnal Konstitusi Vol. II, No. I, Juni 2009 PPK Fakultas Hukum Universitas Brawijaya, Malang, 84.
} 
Amanat Putusan MK yang dimaksud di atas kemudian diikuti dengan perubahan UUPD 2004 dengan diberlakukannya UU No. 12 Tahun 2008 tentang Perubahan Kedua atas UU Republik Indonesia No. 32 Tahun 2004 tentang Pemerintahan Daerah. Dalam konsideran Menimbang huruf b. UU No 12 Tahun 2008 di atas dinyatakan secara tegas: "Untuk mewujudkan kepemimpinan daerah yang demokratis yang memperhatikan prinsip persamaan dan keadilan, penyelenggaraan pemilihan kepala daerah memberikan kesempatan yang sama kepada setiap warga Negara yang memenuhi persyaratan".

Lebih lanjut perubahan No. 3 secara eksplisit dinyatakan sebagai berikut: Ketentuan Pasal 56 ayat (2) diubah, sehingga Pasal 56 berbunyi sebagai berikut:

(1) Kepala daerah dan wakil kepala daerah dipilih dalam satu pasangan calon yang dilaksanakan secara demokratis berdasarkan asas langsung, umum, bebas, rahasia, jujur, dan adil.

(2) Pasangan calon sebagaimana dimaksud pada ayat (1) diusulkan oleh partai politik, gabungan partai politik, atau perseorangan yang didukung oleh sejumlah orang yang memenuhi persyaratan sebagaimana ketentuan dalam Undang-undang ini.

Menurut Undang-undang No.12 Tahun 2008 (selanjutnya disebut UUPD 2008), persyaratan dan mekanisme pencalonan Kepala Daerah diatur sebagai berikut:

1. Pencalonan melalui partai politik sekurang-kurangnya $15 \%$ (lima belas persen) dari jumlah kursi DPRD atau 15\% (lima belas persen) dari akumulasi perolehan suara sah dalam pemilihan umum anggota DPRD di daerah yang bersangkutan.

2. Jika diajukan oleh gabungan partai politik, suara partai politik tersebut juga harus memenuhi $15 \%$. Partai politik yang tidak 
memenuhi $15 \%$ dapat melakukan koalisi dengan partai lain untuk mencalonkan pasangan Kepala Daerah.

3. Untuk Calon perorangan diatur dalam 2 (dua) kategori sebagai berikut:

Pasangan calon perseorangan untuk gubernur dan wakil gubernur dapat mendaftarkan diri sebagai pasangan calon apabila memenuhi syarat dukungan dengan ketentuan:

a. Provinsi dengan dukungan jumlah penduduk sampai dengan 2.000.000 (dua juta) jiwa harus didukung sekurang-kurangnya $6,5 \%$ (enam koma lima persen)

b. Provinsi dengan jumlah penduduk lebih dari 2.000 .000 (dua juta) sampai dengan 6.000.000 (enam juta) jiwa harus didukung sekurang-kurangnya 5\% (lima persen)

c. Provinsi dengan jumlah penduduk lebih dari 6.000 .000 (enam juta) sampai dengan 12.000 .000 (dua belas juta) jiwa harus didukung sekurang-kurangnya $4 \%$ (empat persen); dan

d. Provinsi dengan jumlah penduduk lebih dari 12.000 .000 (dua belas juta) jiwa harus didukung sekurangkurangnya $3 \%$ (tiga persen). Jumlah dukungan sebagaimana dimaksud di atas tersebar di lebih dari 50\% (lima puluh persen) jumlah kabupaten / kota di provinsi dimaksud.

Sedangkan, untuk pasangan calon perseorangan yang dapat mendaftarkan diri sebagai pasangan calon Bupati dan Wakil Bupati, atau Walikota dan Wakil Walikota, apabila memenuhi syarat dukungan dengan ketentuan:

a. Kabupaten/Kota dengan jumlah penduduk sampai dengan 250.000 (dua ratus lima puluh ribu) jiwa harus didukung sekurang-kurangnya 6,5\% (enam koma lima persen).

b. Kabupaten/kota dengan jumlah penduduk lebih dari 250.000 (dua ratus lima puluh ribu) sampai dengan 500.000 (lima 
ratus ribu) jiwa harus didukug sekurang-kurangnya 5\% (lima persen); dan

c. Kabupaten/Kota dengan jumlah penduduk lebih dari 500.000 (lima ratus ribu) sampai dengan 1.000.000 (satu juta) jiwa harus didukung sekurang-kurangnya $4 \%$ (empat persen);dan

d. Kabupaten/Kota dengan jumlah penduduk lebih dari 1.000 .000 (satu juta) jiwa harus didukung sekurangkurangnya $3 \%$ (tiga persen). Jumlah dukungan sebagaimana dimaksud di atas tersebar di lebih dari 50\% (lima puluh persen) jumlah kecamatan di kabupaten/kota dimaksud.

Ketentuan di atas menunjukkan bahwa calon perseorangan yang menjadi calon kepala daerah dan wakil kepala daerah wajib mengumpulkan dukungan dari konstituennya. Dukungan ini dapat dilakukan dengan surat pernyataan dukungan yang terlampir dalam kartu identitas. Jika telah memenuhi persyaratan maka syarat yang telah dikumpul diserahkan kepada Komisi Pemilihan Umum Daerah (KPUD) untuk diverifikasi, dan selanjutnya dilakukan pemeriksaan terhadap syarat-syarat yang telah dilampirkan oleh pasangan bakal calon kepala daerah dan wakilnya. Jika telah dinyatakan lolos verifikasi, maka KPUD menetapkan pasangan calon sekurang-kurangnya 2 (dua) pasangan calon yang dituangkan dalam Berita Acara Penetapan pasangan calon. Proses selanjutnya dilakukan undian secara terbuka untuk menetapkan nomor urut pasangan calon.

Dengan mencermati persyaratan dan mekanisme pendaftaran calon pasangan kepala daerah secara perseorangan seperti ditentukan di atas, terdapat kesulitan dan kendala serta kerumitan prosedural yang dihadapi calon mempersiapkan diri sebagai calon perseorangan, dalam pemilu kepala daerah, yang dapat dirinci seperti berikut: 
1. Bentuk dukungan untuk calon perseorangan harus dibuat dalam bentuk surat pernyataan yang disertai dengan fotokopi Kartu Tanda Penduduk (KTP), atau surat keterangan tanda penduduk sesuai dengan peraturan perundang-undangan. Hal ini menjadi bagian dari kesulitan tersendiri bagi calon perseorangan, karena kondisi manajemen dan administrasi kependudukan di Indonesia masih belum baik dan datanya tidak akurat, dimana masih banyaknya pemegang KTP ganda dan bahkan KTP palsu di masyarakat. Oleh karena itu, menjadi sangat mungkin akan adanya pendukung bayangan dari pasangan calon kepala daerah, dan hal ini akan menjadi masalah teknis baru bagi Komisi Pemilihan Umum Daerah (KPUD) sebagai pelaksana Pemilihan Umum Kepala Daerah.

2. Pengaturan pemilihan kepala daerah berdasarkan UndangUndang Nomor 32 Tahun 2004 tentang Pemerintahan Daerah jo. UU Nomor 12 Tahun 2008 seperti dimaksud di atas pada dasarnya mengandung sejumlah kelemahan, baik dari segi sistem maupun aturan teknisnya. Paradigma UndangUndang Nomor 32 Tahun 2004 meletakkan pemilihan Kepala Daerah sebagai domain Pemerintahan Daerah, dan bukan sebagai domain Pemilihan Umum sebagaimana dimaksud Pasal 22E UUD 1945, sehingga instrumen pelaksana (penyelenggara) dan pelaksanaan (peraturan pelaksanaan) pemilihan Kepala Daerah dapat mengalami bisa pengaruh dan nuansa intervensi Pemerintah. Hal ini dapat berimplikasi pada independensi penyelenggara dan penyelenggaraan pemilihan Kepala Daerah. Padahal prinsip pemilihan langsung yang paling penting adalah dilakukan oleh penyelenggara yang independen sesuai dengan semangat Undang-Undang Nomor 22 Tahun 2007 tentang Penyelenggara Pemilihan Umum.

Oleh karena itu, kemudian Undang-Undang Nomor 22 Tahun 2007 tentang penyelenggaraan pemilihan umum kepala daerah yang berbeda dengan ketentuan dalam Undang-Undang Nomor 
32 Tahun 2004, yaitu dengan menempatkan pemilihan Kepala Daerah sebagai bagian dari pelaksanaan Pemilihan Umum. Dengan demikian, Komisi Pemilihan Umum (KPU) dengan independensinya secara bertanggungjawab dapat menyelenggarakan pemilihan Kepada Daerah secara demokratis berdasarkan asas langsung, umum, bebas, rahasia, jujur, dan adil.

Demikian juga dalam pembentukan Badan Pengawas Pemilu, atau Panitia Pengawas di tingkat lokal, Undang-Undang Nomor 22 Tahun 2007 mengatur pembentukan dan rincian tugasnya serta dijamin independensinya. Perubahan kedua Undang-Undang Nomor 32 Tahun 2004 yang dituangkan dalam Undang-Undang Nomor 12 Tahun 2008 juga secara konkrit telah merevisi substansi ketentuan yang mengatur penyelenggaraan pemilihan Kepala Daerah, khususnya untuk mengakomodasi keberadaan calon perseorangan dalam pemilihan umum Kepala Daerah.

\section{Implikasi Yuridis Mekanisme Pencalonan Kepala Daerah secara Perseorangan}

Implikasi yuridis-politis yang muncul kemudian dari mekanisme pencalonan kepala daerah secara perseorangan adalah: 1. Di satu sisi persyaratan yang harus dipenuhi dan mekanisme yang harus dilalui calon perseorangan untuk mengikuti pemilihan kepala daerah menjadi rumit dan cukup berat.

2. Tetapi, disisi lain bagi calon perseorangan yang kemudian berhasil memenangkan pemilihan kepala daerah, setelah menjadi kepala daerah dan wakil kepala daerah definitif dapat dipastikan akan berhadapan dan harus dapat menjalin kerjasama dengan para anggota Dewan Perwakilan Rakyat Daerah (DPRD) yang berasal dan mewakili partai-partai, dalam melaksanakan tugas dan kewajibannya sebagai kepala daerah dalam penyelenggaraan pemerintahan daerah. 
Padahal secara psiko-politis para anggota DPRD cenderung mendukung kepala daerah yang diusung oleh partainya, sehingga dalam melaksanakan tugas dan kewajibannya untuk menjalankan roda pemerintahan sehari-hari sampai pada kewajiban menyampaikan pertanggungjawaban akhir tahun sebagai kepala daerah yang berasal dari calon perseorangan akan menemui kendala politis dalam membangun hubungan yang harmonis dengan anggota DPRD yang mewakili partaipartai politik tertentu.

Dari perspektif yuridis-sosiologis bahwa pemilihan Kepala Daerah dari unsur calon perseorangan merupakan inovasi hukum dari Mahkamah Konstitusi (MK) yang harus ditindaklanjuti dengan penuh tanggungjawab, sekaligus proses pembelajaran berdemokrasi yang hakiki (geneuine democracy) dengan mengedepankan aspek yuridis-formal dan konstitusional sebagai tolak ukur berhasil tidaknya calon perseorangan menjalankan tugas dan kewajibannya sebagai Kepala Daerah.

Dari perspektif yuridis-empiris pemilihan umum kepala daerah dari calon perseorangan untuk pertama kalinya di Indonesia telah dilaksanakan di Provinsi Nangroe Aceh Darussalam yang diselenggarakan oleh KIP. Calon perseorangan dalam pemilihan Kepala Daerah di Provinsi Aceh ini ternyata mendapat sambutan yang luar biasa dari masyarakat. Bahkan Gubernur Nangroe Aceh Darussalam sekarang, Irwandi Yusuf, merupakan kepala daerah yang berasal dari calon perseorangan. Fakta empiris dalam kehidupan demokrasi di Indonesia dalam bentuk pemilu Kepala Daerah seperti ini menunjukkan bahwa tak selamanya partai politik atau gabungan partai politik mempunyai kemampuan untuk menyerap aspirasi politik masyarakat untuk memilih calon yang diusungnya dalam Pemilihan umum Kepala Daerah. 
Dari uraian diatas dapat diketahui bahwa masalah pengaturan hukum mengenai pemilihan umum kepala daerah memperlihatkan perkembangan dan dinamika yang positif bagi perwujudan kehidupan demokrasi di Indonesia, dengan membuka ruang politis dan hukum bagi kesempatan calon perseorangan, selain calon yang diusung partai politik dan gabungan partai politik, untuk mengikuti pemilihan kepala daerah baik ditingkat provinsi, kabupaten maupun kota. Fenomena dinamika hukum dan kehidupan politik di Indonesia, khususnya dalam kaitan dengan pelaksanaan pemilu kepala daerah, memperlihatkan perkembangan positif dimana amanah konstitusi negara, UUD Tahun 1945 yang mengatur hak politik warga negara yang sama dihadapan hukum dan pemerintahan telah diakomodasi, direspon, dan dilaksanakan secara konsisten tanpa perlakuan diskriminasi.

\section{Tinjauan Fikih Siyasah terhadap Pencalonan Kepala Daerah} Perseorangan

Islam adalah agama yang dianugerahkan kepada seluruh manusia melalui seorang Nabi terakhir yang ummi sebagai tuntunan untuk memperoleh kebahagiaan di Dunia dan Akhirat. Sebagai sebuah anugerah dari yang maha Esa tentunya segala sesuatu yang ada di dalamnya adalah murni hanya untuk kepentingan umat, karena Allah adalah dzat yang suci dari tujuantujuan pribadi. Bermula dari hal tersebut dan dalil-dalil nash maka Ulama' membuat sebuah kaidah pokok dari tujuan syari'at yaitu mendatangkan berbagai kemaslahatan serta menolak berbagai kerusakan "maslahah mursalah".

Para mujtahid menggunakan konsep ini dalam menghasilkan produk-produk hukum karena mereka semua sepakat bahwa syari'at Islam telah membuktikan bahwa ia adalah agama yang 
mampu menjawab berbagai tantangan dari perkembangan zaman dan peradaban yang yang selalu berubah-ubah di tiap situasi dan kondisi, sebagaimana kaidah "la yunkiru taghyir al-ahkam bi taghyir al-zaman". ${ }^{6}$

Menurut istilah umum Maslahah adalah mendatangkan segala bentuk kemanfaatan atau menolak segala kemungkinan yang merusak. Lebih jelasnya Manfaat adalah ungkapan dari sebuah kenikmatan atau segala hal yang masih berhubungan denganya, sedangkan kerusakan adalah hal-hal yang menyakitkan atau segala sesuatu yang ada kaitan denganya.

Pandangan terhadap maslahah terbagi menjadi dua bagian, yaitu pandangan maslahah menurut kaum sosialis materialis serta pandanganya menurut syara' (hakikat syara'), dalam pembahasan pertama al Syatiby mengatakan: "maslahah ditinjau dari segi artinya adalah segala sesuatu yang menguatkan keberlangsungan dan menyempurnakan kehidupan manusia, serta memenuhi segala keinginan rasio dan syahwatnya secara mutlak". Sedangkan menurut arti secara Syara' adalah segala sesuatu yang menguatkan kehidupan di dunia tidak dengan cara merusaknya serta mampu menuai hasil dan beruntung di akhirat, dalam hal ini al-Syatiby mengatakan, "menarik kemaslahatan dan membuang hal-hal yang merusak bisa juga disebut dengan melaksanakan kehidupan di dunia untuk kehidupan di akhirat" sedangkan menurut al-Ghazali maslahah adalah: "memelihara tujuan daripada syari'at". Sedangkan tujuan syara' meliputi lima dasar pokok, yaitu: 1. melindungi agama (hifd al-din), 2. melindungi jiwa (hifd al-nafs), 3.

${ }^{6}$ Muhammad Iqbal, Fiqh Siyasah; Kontekstualisasi Doktrin Politik Islam, (Jakarta: Media Pratama, 2007), 16. 
melindungi akal (hifd al-aql), 4. melindungi kelestarian manusia (hifd al-nasl), 5. melindungi harta benda (hifd al-mal). ${ }^{7}$

Dalam perspektif fikih siyasah, konsep mekanisme calon perseorangan sesuai dengan konsep maslahah ammah, hurriyyah alra'y, dan hurriyyah al-syakhsiyyah:

1. Maslahah Ammah

Maslahah 'ammah adalah kemaslahatan umum yang menyangkut kepentingan orang banyak. Kemaslahatan umum ini tidak berarti untuk kepentingan semua orang, tetapi bisa berbentuk kepentingan mayoritas umat. Misalnya ulama memperbolehkan membunuh penyebar bid'ah yang dapat merusak akidah umat, karena menyangkut kepentingan orang banyak.

Berdasarkan uraian di atas, kemaslahatan umat merupakan sesuatu yang sentral dalam kajian fiqh siyasah khususnya siyasah dusturiyyah, sehingga kebijakan apapun maupun perundang-undangan yang hendak diberlakukan oleh penguasa harus selalu mempertimbangkan dan memperhatikan akibat yang akan ditimbulkan. Dengan kata lain, apakah menimbulkan kemaslatan bagi umat atau malah sebaliknya. Dalam hal ini calon perseorangan yang mencalonkan diri sebagai kepala daerah tentunya tidak dapat ditolak keberadaannya secara syariat ini dikarenakan tidak semua keinginan serta kepentingan warga dan masyarakat terakomodasi oleh adanya partai politik sehingga sangat diperlukan orang yang tidak terafiliasi dengan partai dalam arti pencalonan perseorangan untuk menjaga kemashlahatan umat ini. Keputusan baru yang telah dikeluarkan oleh MK dalam hal ini sangat relevan dan tidak bertentangan dengan nilai-nilai keislaman. MK telah memenuhi persyaratan

7 M.Ibn Ahmad Taqiyah. 1999." Masadiru Al-Tasyri' Al-Islamy", (Lebanon: Muasisu Al Kitab Al Tsaqafiyah, 1999), 138. 
kemashlahatan ummat yang harus terjaga dibanding kepetingan pribadi partai-partai politik tersebut.

Berkaitan dengan hal tersebut, bahwa apabila UU atau ketentuan yang sebelumnya ternyata tidak sesuai dengan tuntutan perkembangan masyarakat, maka harus dirubah. Meskipun secara politis kepala daerah dari calon perseorangan mendapatkan dukungan politis secara minoritas di lembaga DPRD, namun jika kepala daerah tersebut dapat menunjukkan prestasi kerja dan pengabdian kepada masyarakat di daerahnya dengan penuh tanggungjawab dan dapat mensejahterakan rakyatnya, serta tidak melanggar hukum dalam kinerjanya sebagai kepala daerah, maka kepala daerah tersebut walaupun berasal dari calon perseorangan semestinya juga akan memperoleh dukungan politik dari para anggota DPRD dan dukungan moral dari rakyat yang dipimpinnya, karena kemampuan tersebut berarti berusaha melindungi kemashlahatan masyarakat yang lebih luas, yang lebih uatama daripada segelintir orang saja, al-maslahah al-'ammah muqaddamatun 'ala maslahat al-Khamsah. ${ }^{8}$

2. Hurriyah al-Ra'y (Kebebasan berpendapat)

Dalam kerangka fiqh Islam, kebebasan mengemukakan pendapat biasa disebut dengan istilah hurriyyah al-ra'y, yang secara etimologis berarti kebebasan berpendapat yang juga berarti kebebasan berbicara. Penggunaan istilah hurriyah al$r a^{\prime} y$ dan bukan hurriyah al-qawl menunjukkan bahwa para ulama dan sarjana muslim telah menempatkan kedudukan yang amat penting dalam tradisi pemikiran dan keilmuan Islam. Istilah $r a^{\prime} y$ dalam tradisi pemikiran dan keilmuan Islam biasanya dibagi ke dalam tiga jenis, yaitu yang terpuji, tercela, dan diragukan. Jenis $r a^{\prime} y$ atau pendapat yang terpuji adalah $r a^{\prime} y$ yang dijelaskan dalam al-Quran, Sunnah, pendapat para

${ }^{8}$ Muhakki, "Mekanisme Suara Terbanyak Bagi Pemilu Legislatif (Studi Siyasah Dusturiyah)", Jurnal al-Daulah, No. 2, Vol. I (Oktober,20I I), 167. 
sahabat, $r a^{\prime} y$ yang merupakan hasil ijtihad, dan $r a^{\prime} y$ yang dicapai melalui proses musyawarah. $R a^{\prime} y$ yang tercela ( $a l-r a^{\prime} y$ al-mazmumah) dikenal dalam tiga jenis $r a^{\prime} y$, yaitu bid'ah (pembaharuan yang merusak dan menyesatkan), hawa (niat jelek) dan baghy (pelanggaran hukum). Dalam usul al-figh, ra'y biasanya didefinisikan sebagal pendapat tentang suatu masalah yang tidak diatur dalam ai-Quran dan Sunnah. Ia merupakan pendapat yang dipertimbangkan dengan matang, yang dicapai sebagai hasil pemikiran yang mendalam dan dilakukan dengan usaha yang keras dari seseorang. Dengan demikian hurriyyah al-ra'y mensyaratkan adanya pendapat dan pemikiran yang matang, mendalam dan sungguhsungguh.

Setiap orang boleh mengemukakan pendapat sejauh tidak melanggar hukum yang mengandung penghujatan dan fitnah, serta didasarkan pada argumen yang logis, faktual dan bertanggung jawab. Dalam kacamata pemikiran dan keilmuan Islam, $r a^{\prime} y$ dibatasi secara nyata oleh wahyu Tuhan (al-Quran dan Sunnah). Tetapi jika tersedia aturan dan pedoman dalam wahyu, atau jika kedua sumber tersebut (alQuran dan Sunnah) hanya memuat aturan atau pedoman yang masih memungkinkan untuk ditafsirkan, maka hal tersebut masih terbuka untuk $r a^{\prime} y$. dan hak untuk mendapatkan persamaan (al-musyawah) di muka hukum dan pemerintahaan. Jika kita korelasikan dengan Undang-undang yang dikeluarkan oleh Mahkamah Konstitusi (MK) serta sesuai dengan amanat UUD NRI pasal 28E ayat 3 bahwa "setiap orang berhak atas kebebasan berserikat, berkumpul, dan mengeluarkan pendapat..." Ini sejalan dengan corak demokrasi Indonesia sehingga dalam keadaan pemilihan kepala daerah siapapun berhak menyatakan dirinya untuk maju sebagai calon kepala daerah dengan atau tanpa partai politik. Ketentuan ini mengakomodasi setiap hak-hak asasi warga negara yang ingin memajukan bangsa dan negaranya 
serta tidak berafiliasi dengan partai politik manapun tetapi tetap bercita-cita memperjuangkan kepentingan bangsa dan negara. Fakta ini seiring dengan pernyataan bahwa partai politik itu cenderung mementingkan kepentingan partainya dan bukan rakyat. Seperti dijelaskan oleh Maurice Duverger ${ }^{9}$ pada bagian pertama abad ke sembilan belas para aktivis yang aktivitasnya mengacu pada partai mereka lebih sering mengutamakan berpikir tentang ideologi daripada mengenai manusianya. Sehingga kebenaran yang dipegang pun lebih cenderung pada kebenaran dari ideologi partai yang menjadi panutannya dari pada kebenaran yang universal. ${ }^{10}$

3. Hurriyah Al-Syakhsiyyah (Kebebasan Berprilaku)

Dalam UUD NRI pasal 28E ayat 2 ditegaskan bahwa "setiap orang berhak atas kebebasan meyakini kepercayaan, menyatakan pikiran dan sikap, sesuai dengan hati nuraninya dan juga pasal 28I ayat (1) hak untuk hidup, ...hak kemerdekaan pikiran dan hati nurani, ...hak untuk di akui sebagai pribadi di hadapan hukum..."

Dan ayat (2) bahwa setiap orang berhak bebas dari perlakuan yang bersifat diskriminatif atas dasar apapun dan berhak mendapatkan perlindungan terhadap perlakuan diskriminatif itu.

Di dalam Islam, secara khusus Hukum Tata Negara Islam ketentuan ini dikenal dengan Hurriyah Al-Syakhsiyyah dalam arti kebebasan berprilaku secara khusus dan Hak-Hak Asasi Manusia secara umum yang telah diatur dalam Islam juga. Siapapun diberikan hak sebesar-besarnya untuk berprilaku secara bebas namun dalam menjalankan hak dan kebebasannya itu setiap orang wajib tunduk atas batasan-batasan yang telah diberikan oleh agama maupun negara yang terejawantah di dalam undangundang dan nilai-nilai keislaman dengan maksud semata-mata

9 Maurice Duverger. Party Politics and Pressure Groups A Comperative Introduction, (Bina Aksara: |99|), 5.

10 M. Hasbi Amiruddin, Konsep Negara Menurut Fazlur Rahman, (Jakarta: UII Press, 2000), I39

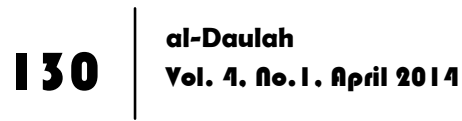


untuk menjamin pengakuan serta penghormatan atas hak dan kebebasan orang lain serta untuk memenuhi tuntutan yang adil sesuai dengan pertimbangan moral nilai-nilai agama dan kebangsaan dan ketertiban atau kemaslahatan umat.

Kepala daerah yang bertindak sebagai pengontrol, pemimpin, dan pengawas bagi berjalannya kebebasan itu sudah seharusnyalah juga dipilih berdasarkan asas kebebasan tersebut. Tidak ada yang boleh melarang siapapun untuk mencalonkan diri sebagai kepala daerah baik itu melalui partai ataupun dengan jalan perseorangan karena itu akan melanggar kebebasan dan hak warga negara untuk membela negaranya. Kebutuhan untuk menjalankan pemilihan kepala daerah langsung dengan sistem yang ditentukan dalam UU No. 32 Tahun 2004 pada dasarnya merupakan amanat dari konstitusi hasil amandemen kedua, kendati tidak secara tegas dinyatakan kata-kata pemilihan secara langsung. Pasal 18 ayat (4) Undang-Undang Dasar 1945 hasil perubahan kedua menyatakan bahwa "gubernur, bupati, walikota, merupakan masing-masing sebagai kepala pemerintahan daerah provinsi kabupaten dan kota dipilih secara demokratis." Perkataan dipillih secara demokratis dapat ditafsirkan secara luas. Yang dapat saja ditafsirkan dipilih secara langsung melalui sistem perwakilan DPRD pada semua tingkatannya. Melihat hal ini Islam sangat mengedepankan kemaslahatan luas bagi rakyat untuk memilih siapa calon pemimpinnya baik itu dari partai maupun tidak. Logikanya, apabila partai politik sudah tidak bisa lagi menjaga kemaslahatan tersebut dan tidak mampu mempertanggung jawabkannya terhadap rakyat secara sosial maka alternatif lain berupa pilihan calon perseorangan non-partai menjadi pilihan yang telah sesuai dengan asas perlakuan tanpa diskriminasi kebebasan berpendapat dan hak asasi manusia bagi calon pemimpin yang tidak berafiliasi dengan partai. 


\section{Penutup}

Implikasi Yuridis setelah diakomodasinya calon perseorangan dalam pemilu kepala daerah pasca Putusan Mahkamah Konstitusi No. 5/PUU-V/2007 adalah perubahan peraturan perundangundangan yang relevan dalam pemilu kepala daerah secara langsung, yaitu Undang-Undang Nomor 32 Tahun 2004 Tentang Pemerintahan Daerah; UU. No. 2 Tahun 2008 tentang Partai Politik, UU No. 10 Tahun 2008 tentang Pemilu Anggota DPR, DPD, dan DPRD; Undang-Undang Nomor 22 Tahun 2007 Tentang Penyelenggaraan Pemilihan Umum, PP. No.6 tahun 2005 tentang Pemilihan, pengesahan pengangkatan, dan pemberhentian kepala dan wakil kepala daerah, yang kemudian dirubah menjadi PP No. 17 Tahun 2005 (Perubahan I), serta PP No. 25 Tahun 2007 (Perubahan II).

Sebelum Keputusan Mahkamah Konstitusi No. 5/PUU-V/2007 keluar, sebenarnya calon perseorangan bisa memasuki dua lembaga politik; Pertama, dalam pemilu 2004 calon perseorangan berlomba-lomba masuk ke lembaga Dewan Perwakilan Daerah Republik Indonesia (DPD RI); Kedua, dengan Undang-Undang No. 11 Tahun 2006 tentang Pemerintahan Aceh, calon perseorangan bisa bersaing bersama calon yang diusung oleh partai politik atau gabungan partai politik nasional dalam pemilihan kepala daerah se-Aceh. Dua jalur pencalonan ini menunjukkan bahwa sistem politik Indonesia sebelum keputusan MK sudah mengenal jalur perseorangan dalam pencalonan jabatan-jabatan politik.

Keluarnya Putusan Mahkamah Konstitusi No. 5/PUU-V/2007, berarti pemilihan kepala daerah yang digelar di berbagai daerah dapat mengikutsertakan pasangan calon perseorangan, meskipun ketentuan-ketentuan teknis pasangan calon perseorangan ini harus diatur, dalam revisi UU No. 32/2004, Peraturan Pemerintahan Pengganti Undang-Undang (Perpu), dengan alasannya: (1) Menjaga momentum agar calon perseorangan diakomodasikan dalam proses pemilihan kepala daerah yang belum melaksanakan pemilihan kepala daerah; (2) Menghindari kepentingan partai 
politik untuk menghambat kehadiran calon perseorangan, terutama yang digerakkan oleh sentiment negatif betapa calon perseorangan akan mematikan partai-partai politik;

Memastikan agar hak-hak perseorangan yang dijamin oleh UUD 1945 itu segera terimplementasikan; dan (4) Memberikan arah yang jelas sebelum pemilihan kepala daerah yang sebenarnya terselenggara.

Sejalan dengan semangat dilaksanakannya pemilian kepala daerah secara langsung yang diikuti calon perseorangan, pengaturan Pemilihan kepala daerah dalam Revisi Terbatas atau Perubahan Kedua Undang-Undang Nomor 32 Tahun 2004 adalah merespon Putusan Mahkamah Konstitusi Nomor 5/PUU-V/2007 tentang calon perseorangan, namun dalam perkembangannya perubahan juga memuat revisi dan pengaturan baru terhadap sejumlah ketentuan yang dipandang penting dalam penyelenggaraan pemerintahan daerah dan pemilihan umum kepala daerah. UU ini memuat aturan tentang keterlibatan calon perseorangan dalam pemilihan kepala daerah. mengenai hal ini, UU menentukan persyaratan dukungan 3\%, 4\%, 5\% dan 6,5\% berdasarkan kluster junlah penduduk. Dukungan tersebut tersebar di lebih dari 50\% jumlah kabupaten/kota (untuk pemilihan kepala daerah provinsi) atau lebih dari 50\% jumlah kecamatan (untuk pemilihan kepala daerah kabupaten/kota). Adapun Pasal 59 tentang calon kepala daerah dan syarat dukungan sesuai Undang No. 12 Tahun 2008.

Secara Fikih siyasah, mekanisme calon perseorangan dalam PEMILUKADA sesuai dengan konsep maslahah al-ammah. maslahah al-'ammah adalah kemaslahatan umum yang menyangkut kepentingan orang banyak. Kemaslahatan umum ini tidak berarti untuk kepentingan semua orang, tetapi bisa berbentuk kepentingan mayoritas umat. Dalam hal ini siapapun calon perseorangan yang maju sebagai kepala daerah tidak bisa didiskriminasi dan berhak mendapatkan hak untuk mencalonkan diri sehingga sejalan dengan keputusan MK tersebut. Sedangkan 
hurriyyah al-ra'y, yang secara etimologis berarti kebebasan berpendapat yang juga berarti kebebasan berbicara. Bahwa siapapun berhak mengeluarkan pendapatnya untuk kemajuan dan kesejahteraan rakyat banyak dengan atau tanpa partai politik, sehingga mengurangi batasan terbatasnya hak-hak asasi manusia yang terbatas hanya dalam partai politik. Yang pada akhirnya akan melahirkan hurriyah al-Syakhsiyyah dalam arti kebebasan berprilaku secara khusus dan Hak-Hak Asasi manusia secara umum yang telah diatur dalam Islam juga. Dalam hal kepala daerah ini sangat berpengaruh untuk mengedepankan hak-hak manusia dan rakyat.

\section{Daftar Pustaka}

Amiruddin, M. Hasbi. Konsep Negara Menurut Fazlur Rahman. Jakarta: UII Press, 2000.

Duverger, Maurice. Party Politics and Pressure Groups A Comperative Introduction. Bina Aksara: 1991.

Electoral Commission. Everything You Need to Know about Voting Under MMP. Wellington: GP Publication, 1996.

-------- The New Zealand Electoral Compendium. Wellington: GP Publication, 1997.

Erawan, I Ketut Putra. "Logika Perubahan dan Keterlanjutkan Sistem Pemilihan Umum bagi Indonesia 2009," makalah disampaikan pada seminar Mencari Format Baru Pemilu dalam Rangka Penyempurnaan UU Bidang Politik, kerjasama Departemen Dalam Negeri dan Lembaga Ilmu Pengetahuan Indonesia, Jakarta, 10 Mei 2006.

Iqbal, Muhammad. Figh Siyasah; Kontekstualisasi Doktrin Politik Islam. Jakarta: Media Pratama, 2007.

Muhakki. "Mekanisme Suara Terbanyak Bagi Pemilu Legislatif (Studi Siyasah Dusturiyah)". Jurnal al-Daulah, No. 2, Vol. 1 (Oktober, 2011). 
Saraswati, Retno. "Calon Perseorangan dalam Pemilihan Kepala daerah, suatu Tinjauan Filosofis", dalam Jurnal Konstitusi Vol. II, No. 1, Juni 2009 PPK Fakultas Hukum Universitas Brawijaya, Malang.

Sumber Depatemen Dalam Negeri. Laporan Pelaksanaan Pemilihan, Pengesahan dan Pelantikan KDH dan WKDH. Jakarta: 29 Maret 2006.

Taqiyah, M. Ibn Ahmad. Masadir Al-Tasyri' Al-Islamiy. Lebanon: Muassisu Al-Kitab Al-Tsaqafiyah, 1999. 